\title{
Relationship the Work Environment and Leadership with ASN Performance Employee at Secretariat DPRD Office South Bengkulu
}

\section{Hubungan Lingkungan Kerja dan Kepemimpinan dengan Prestasi Kerja Aparatur Sipil Negara (ASN) pada Kantor Sekretariat DPRD Bengkulu Selatan}

\author{
Afridi Midian ${ }^{1) ;}$ Neri Susanti'2); Kaulan ${ }^{2)}$ \\ 1)Study Program of Management, Faculty of Economic, Universitas Dehasen Bengkulu \\ ${ }^{2)}$ Department of Accountancy, Faculty of Economic, Universitas Dehasen Bengkulu \\ Email: ${ }^{1)}$ nearrysanti@gmail.com
}

How to Cite :

Midian, A., Susanti, N., Kaulan. (2021). Relationship the Work Environment and Leadership with ASN Performance Employee at Secretariat DPRD Office South Bengkulu. EMAK: Jurnal Ekonomi Manajemen Akuntansi Dan Keuangan, 2(4). DOI: https://doi.org/10.53697/emak.v2i4

\section{ARTICLE HISTORY}

Received [12 Agust 2021]

Revised [25 Agust 2021]

Accepted [05 October 2021]

\section{KEYWORDS}

The Work Environment, Leadership and Performance Employee

This is an open access article under the $C C-B Y$-SA license

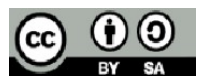

\section{ABSTRAK}

Penelitian ini bertujuan untuk mengetahui hubungan secara parsial antara lingkungan kerja dan kepemimpinan dengan prestasi kerja Aparatur Sipil Negara (ASN) pada Kantor Sekretariat DPRD Bengkulu Selatan. Metode pengumpulan data dengan kuesioner yang diberikan kepada 52 orang Aparatur Sipil Negara (ASN) pada Kantor Sekretariat DPRD Bengkulu Selatan. Analisis data yang digunakan adalah analisis kuantitatif, dengan metode korelasi rank spearman dan pengujian hipotesis dengan uji-t. Hasil penelitian menunjukkan bahwa; korelasi rank spearman $(\rho)$ antara lingkungan kerja dengan prestasi kerja ASN sebesar 0,637, kriteria kuat; korelasi rank spearman ( $\rho$ ) antara kepemimpinan dengan prestasi kerja ASN sebesar 0,557, kriteria sedang. Ada hubungan signifikan antara lingkungan kerja dengan prestasi kerja ASN pada Kantor Sekretariat DPRD Bengkulu Selatan karena nilai thitung lebih besar dari nilai ttabel atau 5,844 $>1,676$, sehingga Ho ditolak dan Ha diterima. Ada hubungan signifikan antara kepemimpinan dengan prestasi kerja ASN pada Kantor Sekretariat DPRD Bengkulu Selatan karena nilai thitung lebih besar dari nilai ttabel atau $4,742>1,676$, sehingga Ho ditolak dan Ha diterima.

\section{ABSTRACT}

This research aim to know relationship of the work environment and leadership with ASN performance employee at Secretariat DPRD Office South Bengkulu. Method data collecting with propagated kuesioner to 52 employee poepel at Secretariat DPRD Office South Bengkulu. Analysis Data conducted with spearman rank corelation and hypothesis testing with ttest. The result showed spearman rank corelation ( $\rho$ ) of the work environment with performance employee equal to 0,637 , strong criterion; The relationship of organizational culture with performance employee was 0,557 , moderate criterion. There is a significant relationship between the work environment with ASN performance employee at Secretariat DPRD Office South Bengkulu, are known that tcount is greater than ptabel, 5,844 $>$ 1,676, Ho is rejected and $\mathrm{Ha}$ is accepted. There is a significant relationship between leadership with ASN performance employee at Secretariat DPRD Office South Bengkulu, are known that tcount is greater than ttabel, 4,742 >1,676, Ho is rejected and Ha is accepted. 
p-ISSN 2798-0499 e-ISSN 2798-0502

\section{PENDAHULUAN}

Setiap organisasi, baik pemerintah ataupun swasta dituntut untuk dapat mengelola dan mengoptimalkan sumber daya manusia yang dimiliki sehingga dapat menghasilkan prestasi kerja yang tinggi. Prestasi kerja adalah hasil secara kualitas dan kuantitas yang dicapai oleh seseorang pegawai dalam melaksanakan tugasnya, sesuai dengan tanggung jawab yang diberikan kepadanya (Dessler, 2015:117). Prestasi kerja pegawai menjadi perhatian khusus bagi setiap organisasi sebab ketercapaian tujuan organisasi akan tergantung pada prestasi kerja Sumber Daya Manusia (SDM) didalamnya. Disinilah terlihat bagaimana Sumber Daya Manusia (SDM) memainkan peran penting dalam sebuah organisasi. Di antara semua aset yang dimiliki dapat dikatakan bahwa Sumber Daya Manusia (SDM) merupakan aset utama sebagai penentu kelangsungan hidup organisasi.

Tinggi atau rendahnya prestasi kerja seorang pegawai salah satunya ditentukan oleh lingkungan kerja tempat dimana ia bekerja. Pada dasarnya setiap anggota dari suatu organisasi memiliki keinginan untuk dapat bekerja dengan suasana lingkungan kerja yang nyaman agar merasa betah sehingga mampu menciptakan hasil kerja yang optimal. Lingkungan kerja dalam suatu organisasi merupakan salah satu hal penting untuk diperhatikan. Meskipun lingkungan kerja tidak melaksanakan proses kerja dalam suatu organisasi, namun lingkungan kerja mempunyai pengaruh langsung terhadap para pegawai yang melaksanakan proses kerja tersebut. Lingkungan kerja yang memuaskan bagi pegawai dapat meningkatkan prestasi kerja. Sebaliknya, lingkungan kerja yang tidak memadai akan menurunkan prestasi kerja pegawai tersebut dalam pelaksanaan tugas-tugas yang diberikan.

Nitisemito (2011:183) menjelaskan bahwa lingkungan kerja adalah segala sesuatu yang ada di sekitar pekerja yang dapat mempengaruhi dirinya dalam menjalankan tugas-tugas yang dibebankan kepadanya. Lingkungan kerja terbagi atas dua, yaitu lingkungan kerja fisik (physical working environment) dan ingkungan kerja non-fisik (non-phisical working environment).

Di samping lingkungan kerja, yang dapat menentukan prestasi kerja seorang pegawai adalah faktor kepemimpinan. Kepemimpinan merupakan ujung tombak bagi semua organisasi dalam menjalankan roda organisasinya. Keberhasilan organisasi ataupun lembaga/instansi dalam mencapai tujuannya akan bergantung pada efektivitas kepemimpinan yang ada dalam organisasi ataupun lembaga/instansi tersebut.

Pemimpin yang ada dalam sebuah organisasi atau lembaga haruslah memiliki kelebihankelebihan bila dibandingkan dengan bawahannya, sehingga dapat menunjukkan kepada bawahan bagaimana cara berbuat dan berdaya-upaya yang terbaik untuk mencapai berbagai tujuan yang telah ditetapkan. Kepemimpinan diartikan sebagai kemampuan yang melekat pada diri seseorang pemimpin untuk mempengaruhi perilaku baik perorangan maupun kelompok (Thoha, 2015:108).

Sekretariat DPRD Bengkulu Selatan merupakan unsur pelayanan administrasi dan pemberian dukungan terhadap tugas dan fungsi DPRD Bengkulu Selatan. Sekretariat DPRD Bengkulu Selatan dipimpin oleh seorang Sekretaris yang dalam melaksanakan tugasnya secara teknis operasional berada di bawah dan bertanggung jawab kepada pimpinan DPRD Bengkulu Selatan, dan secara administratif bertanggungjawab kepada Bupati Bengkulu Selatan melalui Sekretaris Daerah Bengkulu Selatan. Sekretariat DPRD Bengkulu Selatan mempunyai tugas menyelenggarakan administrasi kesekretariatan dan keuangan, mendukung pelaksanaan tugas dan fungsi DPRD, serta menyediakan dan mengoordinasikan tenaga ahli yang diperlukan oleh DPRD dalam melaksanakan hak dan fungsinya sesuai dengan kebutuhan.

Sebagai pendukung penyelenggaraan tugas-tugas yang cukup berat tersebut, sehingga tugas-tugas dan fungsi DPRD Bengkulu Selatan dapat berjalan secara optimal dan sesuai dengan amanat undang-undang, Sekretariat DPRD Bengkulu Selatan mempunyai beberapa fungsi, yaitu penyelenggaraan administrasi kesekretariatan DPRD, penyelenggaraan administrasi keuangan DPRD, fasilitasi penyelenggaraan rapat DPRD, dan penyediaan dan pengoordinasian tenaga ahli yang diperlukan oleh DPRD. 
Untuk melaksanakan semua tugas/pekerjaan itu, Sekretariat DPRD Bengkulu Selatan membutuhkan para pegawai yang memiliki prestasi kerja yang tinggi, sehingga dalam hal ini Sekretariat DPRD Bengkulu Selatan harus memiliki kondisi linkungan kerja yang nyaman dan kondusif bagi pegawai dalam melaksanakan tugas/pekerjaan, serta kepemimpinan yang baik dan efektif dari seorang Sekretaris Dewan. Dengan demikian, pegawai Serkretariat DPRD Bengkulu Selatan akan mampu menunjukkan prestasi kerja yang tinggi dalam menyelesaikan tugas-tugas atau pekerjaan sesuai dengan tanggung jawab yang diberikan kepadanya.

Dari hasil observasi pra penelitian diperoleh informasi bahwa ada beberapa permasalahan yang muncul pada Sekretariat DPRD Bengkulu Selatan, antaralain : Pegawai mengeluh karena fasilitas yang ada berfungsi kurang maksimal seperti koneksi jaringan internet yang kurang baik, permberian ATK kepada pegawai sering terlambat, AC yang kurang berfungsi, pencahayaan yang kurang baik dan seringnya mati lampu, pengambilan keputusan yang dilakukan oleh pimpinan kurang melibatkan bawahan sehingga menghasilkan keputusan yang tidak sesuai dengan kondisi bawahan, masih adanya pegawai yang lalai dalam menyelesaikan tugas, terlambat masuk kerja dan keluar kantor untuk urusan pribadi pada saat jam kerja dengan tanpa izin Pimpinan, hal ini sering terjadi karena masih kurangnya pengawasan dan kurang tegasnya Pimpinan. Semua permasalahan ini tentunya akan berpengaruh terhadap penyelesaian tugas-tugas yang diberikan dan akan berpengaruh terhadap prestasi kerja pegawai secara keseluruhan. Sehingga perlu mendapat perhatian yang serius dari unsur Pimpinan Sekretariat DPRD Bengkulu Selatan.

\section{LANDASAN TEORI}

\section{Lingkungan Kerja}

Pada dasarnya setiap anggota dari suatu organisasi memiliki keinginan untuk dapat bekerja dengan suasana lingkungan kerja yang nyaman agar merasa betah sehingga mampu menciptkanan hasil kerja yang optimal. Lingkungan kerja dalam suatu organisasi termasuk salah satu hal yang penting untuk diperhatikan. Meskipun lingkungan kerja tidak melaksanakan proses kerja dalam suatu organisasi, namun lingkungan kerja mempunyai pengaruh langsung terhadap para pegawai yang melaksanakan proses kerja tersebut. Lingkungan kerja yang memuaskan bagi pegawai dapat meningkatkan prestasi kerja. Sebaliknya, lingkungan kerja yang tidak mernadai akan menurunkan prestasi kerja pegawai tersebut dalam pelaksanaan tugas-tugas yang diberikan.

Menurut Nitisemito (2011:183), lingkungan kerja adalah segala sesuatu yang ada di sekiar pekerja yang dapat mempengaruhi dirinya dalam menjalankan tugas-tugas yang dibebankan kepadanya. Lingkungan kerja adalah suatu lingkungan dimana pegawai bekerja, sedangkan kondisi kerja merupakan dimana pegawai bekerja. Dengan demikian sebenarnya kondisi kerja termasuk salah satu unsur lingkungan kerja dengan kata lain lingkungan kerja di dalam suatu perusahaan bukan hanya terdiri dari kondisi kerja saja melainkan kondisi kerja ditambah dengan aspek lain yang membentuk lingkungan kerja.

\section{Kepemimpinan}

Kepemimpinan merupakan ujung tombak bagi semua organisasi dalam menjalankan roda organisasinya. Keberhasilan organisasi atau lembaga/instansi mencapai tujuannya akan bergantung pada efektifitas kepemimpinan yang ada dalam organisasi ataupun lembaga/instansi tersebut. Pemimpin yang ada dalam sebuah organisasi atau lembaga/ instansi haruslah memiliki kelebihankelebihan dibandingkan dengan bawahannya, sehingga dapat menunjukkan kepada bawahannya bagaimana berbuat dan berdaya upaya yang tinggi untuk mencapai tujuan-tujuan yang telah ditetapkan.

Hal penting yang harus dipahami oleh seorang pemimpin dalam menerapkan kepemimpinan pada sebuah organisasi atau instansi adalah bahwa menjadi seorang pemimpin itu harus mampu mengamati dan menemukan kenyataan dari suatu lingkungan, untuk itu pemimpin harus mampu melihat, mengamati dan memahami keadaan atau situasi tempat kerjanya, dalam 
artian bagaimana para bawahannya, bagaimana keadaan organisasinya, bagaimana situasi penugasannya dan juga bagaimana tentang dirinya sendiri sehingga pemimpin mampu menerapkan kepemimpinan yang tepat (Kartini, 2011:57). Sebelum berbicara lebih mendalam mengenai kepemimpinan, ada baiknya terlebih dahulu kita pahami pengertian pemimpin. Menurut Winardi (2011:2), pemimpin adalah seorang yang karena kecakapan-kecakapan pribadinya dengan atau tanpa pengangkatan resmi dapat mempengaruhi kelompok yang dipimpinnya untuk mengerahkan upaya bersama ke arah pencapaian sasaran-sasaran tertentu.

\section{Prestasi Kerja}

Prestasi kerja (performance) sering disebut juga sebagai kinerja. Suatu organisasi baik pemerintah maupun swasta, besar maupun kecil dalam mencapai tujuan yang telah ditetapkan harus melalui kegiatan-kegiatan yang digerakkan oleh orang atau sekelompok orang yang aktif berperan sebagai pelaku. Dengan kata lain, tercapainya tujuan organisasi hanya dimungkinkan karena adanya upaya yang dilakukan oleh orang dalam organisasi tersebut. Prestasi kerja merupakan hasil kerja yang dicapai oleh seseorang dalam melaksanakan tugasnya sesuai dengan standar dan kriteria yang ditetapkan untuk pekerjaan tersebut. Mangkunegara (2014:65) mengatakan bahwa istilah prestasi kerja berasal dari kata job performance atau actual performance (prestasi sesungguhnya) yang dicapai oleh seseorang. Lembaga Administrasi Negara dalam Sedarmayanti (2010:150) menterjemahkan performance sebagai kinerja, yang juga berarti prestasi kerja, pelaksanaan kerja, pencapaian kerja atau hasil kerja.

Prestasi kerja merujuk kepada tingkat keberhasilan dalam melaksanakan tugas serta kemampuan untuk mencapai tujuan yang telah ditetapkan. Jika tujuan yang diinginkan dapat tercapai dengan baik, maka prestasi kerja dinyatakan baik dan sukses. Prestasi kerja juga dinyatakan sebagai kualitas dan kuantitas dari pencapaian tugas-tugas, baik yang dilakukan oleh individu, kelompok maupun perusahaan (Mamik, 2010:19). Menurut Robbins (2009:49), prestasi kerja merupakan perilaku kerja yang ditampakkan oleh orang-orang yang terlibat dalam suatu perusahaan dan dapat dijelaskan melalui sistem evalusi kerja atau performance appraisal. Prestasi kerja pegawai didefenisikan juga sebagai kemampuan pegawai dalam melakukan sesuatu keahlian tertentu. Prestasi kerja pegawai sangatlah perlu sebab dengan prestasi kerja ini akan diketahui seberapa jauh kemampuan pegawai dalam melaksanakan tugas yang dibebankan kepadanya (Sinambela, 2012:136). Agar memudahkan dalam melakukan pemecahan masalah dan tidakmenyimpang dari permasalahan yang diangkat dalam penelitian ini, maka perlu dibuat kerangka analisis yang menunjukkan langkah dalam pemecahan masalah sebagaimana yang telah dirumuskan. Berdasarkan latar belakang, rumusan masalah dan studi kepustakaan, dapat digambarkan kerangka analisis penelitian seperti gambar 1 berikut :

Gambar 1. Kerangka Analisis

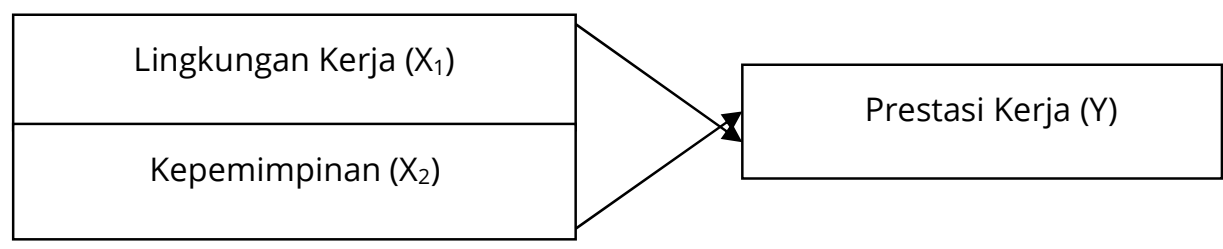

Kerangka analisis di atas menunjukkan bahwa variabel independen yaitu Lingkungan Kerja $\left(X_{1}\right)$ dan Kepemimpinan $\left(X_{2}\right)$, memiliki korelasi dengan variabel dependen Prestasi Kerja $(Y)$. Ini berari, secara parsial ada hubungan antara lingkungan kerja $\left(\mathrm{X}_{1}\right)$ dan kepemimpinan $\left(\mathrm{X}_{2}\right)$ dengan prestasi kerja (Y) Aparatur Sipil Negara (ASN) pada Kantor Sekretariat DPRD Bengkulu Selatan. 


\section{METODE PENELITIAN}

\section{Metode Analisis}

Penelitian yang dilakukan ini merupakan penelitian korelasional. Penelitian korelasional adalah penelitian yang bermaksud menjelaskan kedudukan variabel-variabel yang diteliti serta hubungan antara satu variabel dengan variabel yang lain tanpa ada upaya mempengaruhi variabel tersebut (Sugiyono, 2013:21). Penelitian ini bersifat menggambarkan suatu hubungan antara variabel lingkungan kerja $\left(\mathrm{X}_{1}\right)$ dan variabel kepemimpinan $\left(\mathrm{X}_{2}\right)$ dengan variabel prestasi kerja $(\mathrm{Y})$ Aparatur Sipil Negara (ASN) pada Kantor Sekretariat DPRD Bengkulu Selatan, dimana dalam penganalisaan datanya menggunakan statistik, artinya data yang ada berbentuk kuantitatif, sehingga penelitian ini juga merupakan penelitian kuantitatif.

\section{Korelasi Rank Spearman}

Analisis korelasi rank spearman digunakan untuk mengetahui tingkat hubungan antara lingkungan kerja $\left(\mathrm{X}_{1}\right)$ dan kepemimpinan $\left(\mathrm{X}_{2}\right)$ dengan prestasi kerja $(\mathrm{Y})$ Aparatur Sipil Negara (ASN) pada Kantor Sekretariat DPRD Bengkulu Selatan.

Dalam korelasi rank spearman sumber data untuk kedua variabel yang akan dikorelasikan dapat berasal dari sumber yang tidak sama, jenis data yang dikorelasikan adalah data ordinal, serta data dari kedua variabel tidak harus membentuk distribusi normal. Jadi korelasi rank spearman adalah bekerja dengan data ordinal atau berjenjang atau rangking, dan bebas distribusi (Sugiyono, 2013:357). Rumus korelasi rank spearman adalah :

$\rho=1-\frac{6 \Sigma \mathrm{bi}^{2}}{n\left(n^{2}-1\right)}$

(Sugiyono, 2013:357)

\section{Keterangan :}

P $\quad=$ Koefisien Korelasi Spearman Rank

$\mathrm{n} \quad \quad=$ Jumlah sampel

$\Sigma_{b i} i^{2}=$ Jumlah kuadrat dari selisih rank variabel $\mathrm{X}$ dan variabel $\mathrm{Y}$

\section{HASIL DAN PEMBAHASAN}

\section{Hasil dan Pembahasan}

\section{Analisis Korelasi Rank Spearman}

Analisis korelasi rank spearman dilakukan untuk mengetahui tingkat hubungan bila masingmasing variabel yang dihubungkan berbentuk ordinal. Korelasi rank spearman merupakan data rasio yang dirubah menjadi data ordinal dalam bentuk rangking. Analisis korelasi rank spearman dilakukan untuk mengetahui tingkat hubungan antara lingkungan kerja $\left(\mathrm{X}_{1}\right)$ dan kepemimpinan $\left(\mathrm{X}_{2}\right)$ dengan prestasi kerja Aparatur Sipil Negara (ASN) pada Kantor Sekretariat DPRD Bengkulu Selatan. Hubungan Lingkungan Kerja $\left(\mathrm{X}_{1}\right)$ dengan Prestasi Kerja Aparatur Sipil Negara $(\mathrm{Y})$

Dari lampiran 8, tabel penolong perhitungan korelasi rank spearman variabel $X_{1}$ dengan $Y_{\text {, }}$ diketahui nilai $b_{i}^{2}=8.503,5$ dan $\mathrm{n}=52$. Perhitungan nilai koefisien korelasi rank spearman $(p)$ dapat diuraikan sebagai berikut :

$$
\begin{aligned}
& \rho=1-\frac{6 \Sigma \mathbf{b i}^{2}}{n\left(n^{2}-1\right)} \\
& p=1-\frac{6(8503,5)}{52\left(52^{2}-1\right)}
\end{aligned}
$$




$$
\begin{aligned}
& \rho=1-\frac{51021}{52(2704-1)} \\
& \rho=1-\frac{51021}{52(2703)} \\
& \rho=1-\frac{51021}{140556} \\
& \rho=1-0,363 \\
& \rho=0,637
\end{aligned}
$$

Hasil perhitungan di atas menunjukkan bahwa nilai koefisien korelasi rank spearman $(\rho)$ sebesar 0,637 berada pada interval koefisien 0,60 - 0,799, kriteria 'Kuat'. Ini berarti hubungan antara lingkungan kerja dengan prestasi kerja Aparatur Sipil Negara (ASN) pada Kantor Sekretariat DPRD Bengkulu Selatan adalah kuat.

Hubungan Kepemimpinan $\left(\mathrm{X}_{2}\right)$ dengan Prestasi Kerja Aparatur Sipil Negara $(\mathrm{Y})$. Dari lampiran 9, tabel penolong korelasi rank spearman $\mathrm{X}_{2}$ dengan $\mathrm{Y}$, diketahui nilai $b_{i}^{2}=10.377,5$ dan $\mathrm{n}=52$. Perhitungan nilai koefisien korelasi rank spearman $(\rho)$ dapat diuraikan sebagai berikut :

$$
\begin{aligned}
& p=1-\frac{6 \mathrm{Bbi}^{2}}{n\left(n^{2}-1\right)} \\
& \rho=1-\frac{6(10377,5)}{52\left(52^{2}-1\right)} \\
& \rho=1-\frac{62265}{52(2704-1)} \\
& \rho=1-\frac{62265}{52(2703)} \\
& \rho=1-\frac{62265}{140556} \\
& \rho=1-0,443 \\
& \rho=0,557
\end{aligned}
$$

Dari hasil perhitungan diketahui bahwa besarnya nilai koefisien korelasi rank spearman ( $\rho$ ) sebesar 0,557 berada pada interval koefisien 0,40 - 0,599, kriteria 'Sedang'. Ini berarti hubungan antara kepemimpinan dengan prestasi kerja Aparatur Sipil Negara (ASN) pada Kantor Sekretariat DPRD Bengkulu Selatan adalah sedang.

Pengujian Hipotesis

Pengujian hipotesis dilakukan untuk mengetahui signifikansi hubungan variabel lingkungan kerja $\left(\mathrm{X}_{1}\right)$, kepemimpinan $\left(\mathrm{X}_{2}\right)$ dengan prestasi kerja Aparatur Sipil Negara (ASN) pada Kantor Sekretariat DPRD Bengkulu Selatan. Pengujian hipotesis dilakukan dengan cara membandingkan antara nilai $t_{\text {hitung }}$ dengan nilai $t_{\text {tabel, }}$, dengan ketentuan sebagai berikut :

Hipotesis yang digunakan dalam pengujian ini adalah :

Untuk hipotesis pertama $\left(\mathrm{H}_{1}\right)$

$\mathrm{Ho}_{1} \quad$ : Tidak ada hubungan signifikan antara lingkungan kerja dengan prestasi kerja Aparatur Sipil Negara pada Kantor Sekretariat DPRD Bengkulu Selatan.

$\mathrm{Ha}_{1} \quad$ : Ada hubungan signifikan antara lingkungan kerja dengan prestasi kerja Aparatur Sipil Negara pada Kantor Sekretariat DPRD Bengkulu Selatan.

Untuk hipotesis kedua $\left(\mathrm{H}_{2}\right)$

$\mathrm{Ho}_{2}$ : Tidak ada hubungan signifikan antara kepemimpinan dengan prestasi kerja Aparatur Sipil Negara pada Kantor Sekretariat DPRD Bengkulu Selatan. 
$\mathrm{Ha}_{2}$ : Ada hubungan signifikan antara kepemimpinan dengan prestasi kerja Aparatur Sipil Negara pada Kantor Sekretariat DPRD Bengkulu Selatan.

Level of significant $95 \%$ atau $\alpha=0,05 ; \mathrm{dk}=\mathrm{n}-2=52-2=50$, diperoleh $\mathrm{t}_{\text {tabel }}=1,676$, dengan kriteria pengujian sebagai berikut:

Jika $t_{\text {hitung }}<t_{\text {tabel, }}$ maka Ho diterima dan Ha ditolak, artinya tidak ada hubungan signifikan.

Jika $t_{\text {hitung }}>t_{\text {tabel}}$, maka Ho ditolak dan Ha diterima, artinya ada hubungan signifikan.

Secara rinci pengujian hipotesis hubungan parsial antara variabel $X_{1}$ dan $X_{2}$ dengan variabel $Y$ dapat dijelaskan sebagai berikut :

1. Uji t hubungan lingkungan kerja $\left(\mathrm{X}_{1}\right)$ dengan prestasi kerja ASN $(\mathrm{Y})$

Dengan tingkat keyakinan 95\%, alpha $(\alpha)=0,05, \mathrm{n}=52$, dan $\rho=0,637$, maka dapat ditentukan nilai thitung sebagai berikut :

$$
\begin{aligned}
& t_{\text {hitung }}=r \sqrt{\frac{n-2}{1-r^{2}}} \\
& t_{\text {hitung }}=0,637 \sqrt{\frac{52-2}{1-(0,637)^{2}}} \\
& t_{\text {hitung }}=0,637 \sqrt{\frac{50}{1-0,406}} \\
& t_{\text {hitung }}=0,637 \sqrt{\frac{50}{0,594}} \\
& t_{\text {hitung }}=0,637 x 9,175 \\
& t_{\text {hitung }}=5,844
\end{aligned}
$$

Hasil perhitungan menunjukkan bahwa nilai thitung1 $=5,844$, sedangkan tabel (tingkat keyakinan $95 \%, \alpha=0,05, d k=50)$ sebesar 1,676 , maka $t_{\text {hitung1 }}>t_{\text {tabel }}(5,844>1,676)$. Ini berarti terdapat hubungan signifikan antara lingkungan kerja dengan prestasi kerja Aparatur Sipil Negara (ASN) pada Kantor Sekretariat DPRD Bengkulu Selatan.

2. Uji t hubungan kepemimpinan $\left(\mathrm{X}_{2}\right)$ dengan prestasi kerja $A S N(\mathrm{Y})$

Dengan tingkat keyakinan 95\%, alpha $(\alpha)=0,05, \mathrm{n}=52$, dan $\rho=0,557$, maka dapat ditentukan nilai thitung sebagai berikut:

$$
\begin{aligned}
& t_{\text {hitung }}=r \sqrt{\frac{n-2}{1-r^{2}}} \\
& t_{\text {hitung }}=0,557 \sqrt{\frac{52-2}{1-(0,557)^{2}}} \\
& t_{\text {hitung }}=0,557 \sqrt{\frac{50}{1-0,310}} \\
& t_{\text {hitung }}=0,557 \sqrt{\frac{50}{0,69}} \\
& t_{\text {hitung }}=0,557 \sqrt{\Gamma} 8,513 \\
& t_{\text {hitung }}=4,742
\end{aligned}
$$

Hasil perhitungan menunjukkan bahwa nilai thitung2 $=4,742$, sedangkan tabel (tingkat keyakinan $95 \%, \alpha=0,05, d k=50)$ sebesar 1,676, maka thitung2 $>t_{\text {tabel }}(4,742>1,676)$. Berarti terdapat hubungan 
signifikan antara kepemimpinan dengan prestasi kerja Aparatur Sipil Negara (ASN) pada Kantor Sekretariat DPRD Bengkulu Selatan.

Pembahasan

Bagian pembahasan ini akan memuat rekapitulasi hasil perhitungan korelasi rank spearman dan hasil pengujian hipotesis, dan juga akan dibahas secara rinci hubungan (korelasi) secara parsial antara variabel independen (lingkungan kerja dan kepemimpinan) dengan prestasi kerja Aparatur Sipil Negara (ASN) pada Kantor Sekretariat DPRD Bengkulu Selatan. Hasil perhitungan korelasi dan pengujian hipotesis yang telah dilakukan sebelumnya dapat dirangkum seperti pada tabel 1 berikut :

Tabel 1. Rekapitulasi Hasil Perhitungan Korelasi dan Pengujian Hipotesis

\begin{tabular}{|c|l|c|c|c|c|c|}
\hline No & \multicolumn{1}{|c|}{ Variabel Korelasi } & \multicolumn{1}{|c|}{ Kriteria } & $t_{\text {hitung }}$ & $t_{\text {tabel }} d k=50$ & Kesimpulan \\
\hline 1 & $\begin{array}{l}\text { Lingkungan Kerja dengan Prestasi } \\
\text { Kerja ASN }\end{array}$ & 0,637 & Kuat & 5,844 & 1,676 & $\begin{array}{l}t_{\text {hitung }}>t_{\text {tabel }} \\
\text { (Signifikan) }\end{array}$ \\
\hline 2 & $\begin{array}{l}\text { Kepemimpinan dgn Prestasi Kerja } \\
\text { ASN }\end{array}$ & 0,557 & Sedang & 4,742 & 1,676 & $\begin{array}{l}\text { thitung }>\text { ttabel } \\
\text { (Signifikan) }\end{array}$ \\
\hline
\end{tabular}

Sumber : Hasil penelitian, data diolah, 2020

Dari tabel 1 di atas dapat disimpulkan bahwa secara keseluruhan variabel independen (lingkungan kerja dan kepemimpinan) secara parsial memiliki hubungan yang signifikan dengan variabel dependen (prestasi kerja ASN), karena seluruh nilai $t_{\text {hitung }}>t_{\text {tabel. }}$. Berikut akan disajikan bahasan secara rinci hubungan parsial masing-masing variabel independen dengan variabel dependen.

Hubungan Lingkungan Kerja Dengan Prestasi Kerja Aparatur Sipil Negara (ASN) pada Kantor Sekretariat DPRD Bengkulu Selatan

Berdasarkan hasil analisis korelasi rank spearman dan pengujian hipotesis, dapat dirangkum pada tabel 2 berikut ini :

Tabel 2. Hasil Analisis Korelasi Rank Spearman dan Uji t variabel $X_{1}$

Dengan $Y$

\begin{tabular}{|c|c|c|c|c|c|}
\hline Variabel Korelasi & p & Kriteria & $t_{\text {hitung }}$ & $\begin{array}{l}t_{\text {tabel }} \\
\mathrm{dk}=50\end{array}$ & Keterangan \\
\hline $\begin{array}{l}\text { Lingkungan Kerja dengan } \\
\text { Prestasi Kerja }\end{array}$ & 0,637 & Kuat & 5,844 & 1,676 & $\begin{aligned} & t_{\text {hitung }}>\text { ttabel } \\
& \text { (Signifikan) }\end{aligned}$ \\
\hline
\end{tabular}

Sumber: Hasil penelitian, data diolah, 2020

Dari tabel 2 di atas dapat dijelaskan bahwa antara lingkungan kerja dengan prestasi kerja Aparatur Sipil Negara memiliki hubungan yang kuat, artinya semakin baik lingkungan kerja yang ada pada Kantor Sekretariat DPRD Bengkulu Selatan, maka akan semakin tinggi pula prestasi kerja yang diberikan pegawai kepada lembaga. Hal ini didukung oleh hasil uji $t$, dimana thitung $>t_{\text {tabel, }}$ artinya ada hubungan yang signifikan antara lingkungan kerja dengan prestasi kerja Aparatur Sipil Negara (ASN) pada Kantor Sekretariat DPRD Bengkulu Selatan. Hasil penelitian ini membuktikan bahwa indikator-indikator yang digunakan dalam mengukur variabel lingkungan kerja, yaitu suasana kerja, hubungan dengan rekan kerja, dan tersedianya fasilitas kerja benar-benar berpengaruh terhadap prestasi kerja Aparatur Sipil Negara (ASN) pada Kantor Sekretariat DPRD Bengkulu Selatan.

Hasil kuesioner menunjukkan bahwa total skor tertinggi terdapat pada pernyataan nomor 1 , indikator suasana kerja, yaitu "Kondisi ruangan kerja bersih dan nyaman" dengan skor 240. Ini 
menunjukkan bahwa Aparatur Sipil Negara pada Kantor Sekretariat DPRD Bengkulu Selatan merasa nyaman dengan suasana ruangan kerja yang ada saat ini. Sedangkan total skor terendah terdapat pada pernyataan nomor 3, indikator hubungan dengan rekan kerja, yaitu "Adanya komunikasi yang baik antara atasan dengan bawahan" dengan skor 201. Ini berarti bahwa walaupun komunikasi antara pimpinan dengan bawahan dirasakan sudah baik, namun masih perlu diperbaiki dan ditingkatkan.

Tinggi atau rendahnya prestasi kerja seorang pegawai salah satunya ditentukan oleh lingkungan kerja tempat dimana ia bekerja. Pada dasarnya setiap anggota dari suatu organisasi memiliki keinginan untuk dapat bekerja dengan suasana lingkungan kerja yang nyaman agar merasa betah sehingga mampu menciptakan hasil kerja yang optimal. Lingkungan kerja dalam suatu organisasi termasuk salah satu bagian permasalahan yang penting untuk diperhatikan, karena lingkungan kerja mempunyai pengaruh langsung terhadap para pegawai yang melaksanakan proses kerja tersebut. Lingkungan kerja yang memuaskan bagi pegawai dapat meningkatkan prestasi kerja. Sebaliknya, lingkungan kerja yang tidak mernadai akan menurunkan prestasi kerja pegawai tersebut dalam pelaksanaan tugas-tugas yang diberikan.

Nitisemito (2011:183) menjelaskan bahwa lingkungan kerja adalah segala sesuatu yang ada di sekitar pekerja yang dapat mempengaruhi dirinya dalam menjalankan tugas-tugas yang dibebankan kepadanya. Lingkungan kerja terdiri dari lingkungan kerja fisik (physical working environment) dan ingkungan kerja non-fisik (non-phisical working environment).

Dari hasil penelitian menunjukkan bahwa Aparatur Sipil Negara (ASN) pada Kantor Sekretariat DPRD Bengkulu Selatan menginginkan suatu lingkungan kerja yang menyenangkan dan kondusif, yang meliputi ruang kerja yang bersih dan nyaman, pemimpin yang bijaksana dan adil, rekan kerja yang menyenangkan yaitu saling menghargai, saling percaya dan saling bekerjasama dalam pekerjaan, serta fasilitas kantor yang memadai yang mendukung kelancaran pegawai dalam menyelesaikan pekerjaannya.

Hubungan Kepemimpinan dengan Prestasi Kerja Aparatur Sipil Negara (ASN) pada Kantor Sekretariat DPRD Bengkulu Selatan

Berdasarkan hasil analisis korelasi rank spearman dan pengujian hipotesis, dapat dirangkum seperti pada tabel 3 berikut :

Tabel 3. Hasil Analisis Korelasi Rank Spearman dan Uji t variabel $X_{2}$ Dengan $Y$

\begin{tabular}{|l|c|c|c|c|c|}
\hline \multicolumn{1}{|c|}{ Variabel Korelasi } & $\rho$ & Kriteria & $t_{\text {hitung }}$ & $\begin{array}{c}t_{\text {tabel }} \\
\mathrm{dk}=50\end{array}$ & Keterangan \\
\hline $\begin{array}{l}\text { Kepemimpinan dengan } \\
\text { Prestasi Kerja }\end{array}$ & 0,557 & Sedang & 4,742 & 1,676 & $\begin{array}{l}t_{\text {hitung }}>t_{\text {tabel }} \\
\text { (Signifikan) }\end{array}$ \\
\hline
\end{tabular}

Sumber: Hasil penelitian, data diolah, 2020

Pada tabel 3 di atas terlihat bahwa antara kepemimpinan dengan prestasi kerja Aparatur Sipil Negara memiliki hubungan yang sedang, artinya semakin baik kepemimpinan pada Kantor Sekretariat DPRD Bengkulu Selatan, maka semakin baik pula prestasi kerja yang dapat dicapai oleh para pegawai, walaupun pengaruhnya hanya sedang. Hal ini diperkuat oleh hasil uji hipotesis, dimana $t_{\text {hitung }}>t_{\text {tabel, }}$ artinya ada hubungan yang signifikan antara kepemimpinan dengan prestasi kerja Aparatur Sipil Negara (ASN) pada Kantor Sekretariat DPRD Bengkulu Selatan. Ini membuktikan bahwa indikator-indikator yang digunakan dalam mengukur variabel kepemimpinan, yaitu kepribadian (personality), konsep diri (self-concept), rangsangan (drive), kejujuran (integrity), pengetahuan organisasi (knowledge of the business), kemampuan kognitif dan pengaplikasiannya (cognitive and practical intelligence), dan kemampuan mengatur emosi (emotional intelligence) mempengaruhi prestasi kerja Aparatur Sipil Negara (ASN) pada Kantor Sekretariat DPRD Bengkulu Selatan. 
p-ISSN 2798-0499 e-ISSN 2798-0502

Hasil kuesioner menunjukkan bahwa total skor tertinggi terdapat pada pernyataan nomor 1 , indikator personality, yaitu "Pemimpin memiliki kepribadian yang baik dan teladan" dengan skor 213. Ini berarti bahwa Aparatur Sipil Negara pada Kantor Sekretariat DPRD Bengkulu Selatan menilai bila pimpinan mereka saat ini memiliki kepribadian yang baik dan menjadi teladan bagi mereka. Sementara total skor terendah terdapat pada pernyataan nomor 2, indikator self-concept, yaitu "Pemimpin memiliki konsep kepemimpinan yang positif mengenai keterampilan dan kemampuan dalam mencapai sasaran organisasi" dengan skor 197. Ini menunjukkan kalau Aparatur Sipil Negara pada Kantor Sekretariat DPRD Bengkulu Selatan belum melihat kalau pimpinan mereka saat ini memiliki konsep yang positif terhadap keterampilan dan kemampuan seorang pegawai sebagai dasar dalam mencapai sasaran yang sudah ditetapkan oleh lembaga.

Prestasi kerja seorang Aparatur Sipil Negara juga ditentukan oleh faktor kepemimpinan. Kepemimpinan merupakan ujung tombak bagi semua organisasi dalam menjalankan roda organisasinya. Keberhasilan organisasi ataupun lembaga dalam mencapai tujuannya akan bergantung pada efektivitas kepemimpinan yang ada dalam organisasi ataupun lembaga tersebut. Pemimpin sebuah organisasi atau lembaga haruslah memiliki kelebihan-kelebihan dibandingkan dengan bawahannya, sehingga dapat menunjukkan kepada bawahannya bagaimana berbuat dan berdaya upaya yang tinggi untuk mencapai tujuan yang telah ditetapkan. Kepemimpinan diartikan sebagai kemampuan yang melekat pada diri seseorang pemimpin untuk mempengaruhi perilaku baik perorangan maupun kelompok (Thoha, 2015:108).

Faktor-faktor yang mempengaruhi efektifitas kepemimpinan mencakup kepribadian dan pengalaman masa lampau, harapan dari pemimpin tersebut, harapan dan perilaku atasan, karakteristik, harapan dan perilaku bawahan, persyaratan tugas, kultur, kebijaksanaan organisasi dan harapan serta perilaku rekan kerja. Proses pengaruh tersebut bersifat timbal balik antara pemimpin dan anggota kelompok, sehingga mempengaruhi efektifitas kelompok secara keseluruhan.

Menurut Wibowo (2013:292), faktor-faktor yang harus dimiliki oleh pemimpin dalam kepemimpinan yang efektif, yaitu meliputi kepribadian (personality), konsep diri (self-concept), rangsangan (drive), kejujuran (integrity), pengetahuan organisasi (knowledge of the business), kemampuan kognitif dan pengaplikasiannya (cognitive and practical intelligence), dan kemampuan mengatur emosi (emotional intelligence).

Dari hasil penelitian ini, kepemimpinan terlihat pada sikap dan perilaku Sekretaris DPRD Bengkulu Selatan terutama dalam hal, memiliki kepribadian yang baik dan teladan, memotivasi bawahan untuk mencapai sasaran organisasi, memiliki integritas, serta memiliki pengetahuan yang baik tentang organisasi.

\section{KESIMPULAN DAN SARAN}

Kesimpulan

1. Hubungan antara lingkungan kerja dengan prestasi kerja Aparatur Sipil Negara (ASN) pada Kantor Sekretariat DPRD Bengkulu Selatan adalah kuat, dengan nilai korelasi sebesar 0,637, dan berada pada interval koefisien 0,60-0,799. Hal ini didukung dengan hasil uji hipotesis, dimana nilai thitung > nilai ttabel atau 5,844 > 1,676, maka Ho ditolak dan Ha diterima, artinya antara lingkungan kerja dengan prestasi kerja Aparatur Sipil Negara (ASN) pada Kantor Sekretariat DPRD Bengkulu Selatan memiliki hubungan yang signifikan.

2. Hubungan antara kepemimpinan dengan prestasi kerja Aparatur Sipil Negara (ASN) pada Kantor Sekretariat DPRD Bengkulu Selatan adalah sedang, dengan nilai korelasi sebesar 0,557, dan berada pada interval koefisien 0,40-0,599. Hal ini didukung oleh hasil uji hipotesis, dimana nilai thitung > nilai ttabel atau 4,742 > 1,676, maka Ho ditolak dan Ha diterima, artinya antara kepemimpinan dengan prestasi kerja Aparatur Sipil Negara (ASN) pada Kantor Sekretariat DPRD Bengkulu Selatan memiliki hubungan yang signifikan. 
Saran

1. Untuk dapat meningkatkan prestasi kerja ASN pada Kantor Sekretariat DPRD Bengkulu Selatan, yaitu berupaya menciptakan suasana lingkungan kerja yang menyenangkan bagi para pegawai, terutama berkaitan dengan indikator "Hubungan dengan rekan kerja”. Baik hubungan pimpinan dengan bawahan, maupun hubungan antara sesama pegawai.

2. Dalam menjalankan kepemimpinannya, hendaknya Sekretaris DPRD Bengkulu Selatan bersikap secara jelas dan tegas terutama berkaitan dengan indikator self-concept, yaitu memiliki konsep yang positif terhadap keterampilan dan kemampuan seorang pegawai sebagai dasar dalam mencapai sasaran yang sudah ditetapkan oleh lembaga, serta menjalin komunikasi secara langsung dengan bawahan sesering mungkin berbagai hal tentang lembaga dan kebijakankebijakan.

\section{DAFTAR PUSTAKA}

Dessler, Gary. 2015. Manajemen Sumber Daya Manusia. Edisi 14. Alih Bahasa : Diana Angelica. Jakarta : Salemba Empat.

Gomes, Cardoso, Faustino. 2009. Manajemen Sumber Daya Manusia. Bandung : Remaja Rosdakarya.

Handoko, T. Hani. 2012. Manajemen Personalia dan Sumber Daya Manusia. Yogyakarta : BPFE.

Hasibuan, Malayu S.P. 2016. Manajemen Sumber Daya Manusia. Jakarta : Bumi Aksara.

Mangkunegara, Anwar, Prabu. 2014. Manajemen Sumber Daya Manusia Perusahaan. Bandung : Remaja Rosdakarya.

Kartini, Kartono. 2011. Pemimpin dan Kepemimpinan. Jakarta : RajaGrafindo Persada.

Mamik. 2010. Pengaruh Gaya Kepemimpinan, Motivasi Kerja dan Komitmen Organisasi Terhadap Kinerja Karyawan. Jurnal Ekonomi dan Bisnis Tahun XX. Vol. 1 No. 1.

Martoyo, Susilo. 2010. Manajemen Sumber Daya Manusia. Yogyakarta : BPFE.

Nitisemito, Alex S. 2011. Manajemen Personalia. Jakarta : Galia Indonesia.

Pasolong, Harbani. 2013. Kepemimpinan Birokrasi. Bandung : Alfabeta.

Rivai, Veitzhal dan Ella J. Sagala. 2014. Manajemen Sumber Daya Manusia Untuk Perusahaan : Dari Teori ke Praktik. Jakarta : RajaGrafindo Persada.

Robbins, S.P. 2009. Organizational Behaviour. Buku 2. Edisi 12. Jakarta : Salemba Empat.

Sedarmayanti. 2010. Sumber Daya Manusia dan Produktivitas Kerja. Bandung : Mandar Maju.

Simamora, Hendry. 2013. Manajemen Sumber Daya Manusia. Yogyakarta : STIE YKPN.

Sinambela, Lijan, Poltak. 2012. Kinerja Pegawai : Teori, Pengukuran dan Implikasi. Yogyakarta : Graha Ilmu.

Sugiyono. 2013. Metode Penelitian Kuantitatif Kualitatif dan R\&D. ke-18. Bandung : Alfabeta. 2013. Metode Penelitian Bisnis. Bandung : Alfabeta.

Thoha, Miftah. 2015. Kepemimpinan Dalam Manajemen. Jakarta : RajaGrafindo Persada.

Vidriansyah, Andro. 2014. Analisis Pengaruh Lingkungan Kerja, Kepemimpinan dan Disiplin Kerja terhadap Kinerja Karyawan (Studi pada PT. Indosat Semarang). Skripsi. Semarang : Fakultas Ekonomika dan Bisnis Universitas Diponegoro.

Wahjosumidjo. 2013. Pengembangan Sumber Daya Manusia. Jakarta : Rineka Cipta.

Wexley, K.N., dan G.A. Yukl. 2015. Perilaku Organisasi dan Psikologi Personalia. Jakarta: Bina Aksara. Wibowo. 2013. Manajemen Kinerja. Jakarta : Raja Grafindo Persada.

Winardi. 2011. Kepemimpinan Dalam Manajemen. Jakarta : Rineka Cipta. 